Ярова Ганна Дмитрівна кандидат наук 3 державного управління, доцент кафедри менеджменту та ділового адміністрування приватного вищого навчального закладу Університет штучного інтелекту та цифровізації, 04053, м. Київ, вул. Січових Стрільців, 23 А, тел.: (095) 694-7824, e-mail: yarova2021@ukr.net, https://orcid.org/0000-0003-1043-3742

\title{
ОСОБЛИВОСТІ РОЗВИТКУ ПУБЛІЧНИХ КОМУНІКАЦІЙ В КРАЇНАХ ЄВРОПЕЙСЬКОГО СОЮЗУ
}

Анотація. У статті досліджено особливості розвитку публічних комунікацій у країнах Європейського Союзу, зазначено про важливість публічних комунікацій між інститутами $\mathrm{CC}$, між інститутами $\mathrm{CC}$ та громадськістю, визначено суб'єкти публічних комунікацій, принципи та напрями взаємодій. Визначено, що процес розвитку публічних комунікацій в країнах Свропейського Союзу побудований на чітко визначених принципах та напрямах взаємодії між інститутами влади $€ C$, громадянським суспільством, бізнесом, їх активним залученням до процесів прийняття рішень. Суб'єктами процесу розвитку публічних комунікацій в країнах Європейського Союзу виступають інститути державної влади та управління, інститути місцевого самоврядування, політичні партії, політичні лідери, громадські та міжнародні організації, громадяни, комерційні та підприємницькі структури, інші інституції ЄС. Досліджено функції, які виконують публічні комунікації. Проаналізовано інституційні особливості та цілі комунікаційної політики країн ЄС. Визначено, що процес розвитку публічних комунікацій в країнах Європейського Союзу характеризується такими інституційними особливостями як надання різним заходам, процесам та явищам певної публічності, гласності, відкритості та прозорості; гармонізація та узгодження інтересів всіх учасників; вплив на формування громадської думки та позиції; посилення демократизації, активне залучення громадян до процесів прийняття важливих рішень. Досліджено, що основною метою розвитку публічних комунікацій для громадського суспільства в країнах Європейського Союзу $\epsilon$ надання можливості громадянам отримувати зрозумілу й чітку інформацію про свої права, обов'язки та можливості; активно брати участь у формуванні й реалізації політик, мати доступ до інформації про діяльність та політику СС.

З'ясовано, що процес розвитку публічних комунікацій в країнах Європейського Союзу побудований на принципах інклюзивності, права на свободу висловлювання, права на отримання допомоги в розвитку навичок доступу до інформації; різноманітності, участі, єдиного інформаційного поля. 
Ключові слова: публічні комунікації, Європейський Союз, комунікаційна політика, принципи, функції, цілі.

Yarova Hanna Dmytrivna Candidate of Sciences in Public Administration, Associate Professor of Management and Business Administration University of Artificial Intelligence and Digitization, Management and Business Administration Private Higher Educational Institution, Sichovykh Striltsiv St., 23 A, Kyiv, 04053, tel.: (095) 694-78-24, e-mail: yarova2021@ukr.net, https://orcid.org/0000-00031043-3742

\section{PECULIARITIES OF PUBLIC COMMUNICATIONS DEVELOPMENT IN THE COUNTRIES OF THE EUROPEAN UNION}

Abstract. The article examines the peculiarities of the development of public communications in the European Union, notes the importance of public communications between EU institutions, between EU institutions and the public, identifies the subjects of public communications, principles and directions of interaction. It is determined that the process of development of public communications in the European Union is based on clearly defined principles and areas of interaction between EU institutions, civil society, business, their active involvement in decision-making processes. Institutions of state power and administration, institutions of local self-government, political parties, political leaders, public and international organizations, citizens, commercial and business structures, and other EU institutions are the subjects of the process of development of public communications in the European Union. The functions performed by public communications are investigated. The institutional features and goals of the communication policy of the EU countries are analyzed. It is determined that the process of development of public communications in the countries of the European Union is characterized by such institutional features as giving various measures, processes and phenomena a certain publicity, transparency, openness and transparency; harmonization and coordination of interests of all participants; influence on the formation of public opinion and position; strengthening democratization, active involvement of citizens in important decision-making processes.It is investigated that the main goal of the development of public communications for civil society in the European Union is to enable citizens to receive clear and unambiguous information about their rights, responsibilities and opportunities; actively participate in the formulation and implementation of policies, have access to information on EU activities and policies.

It was found that the process of developing public communications in the European Union is based on the principles of inclusiveness, freedom of expression, the right to receive assistance in developing information access skills; diversity, participation, a single information field. 
Keywords: public communications, European Union, communication policy, principles, functions, goals.

Постановка проблеми. Публічні комунікації виступають одним 3 найдієвіших інструментів сталого розвитку європейського співтовариства. Процеси формування публічних комунікацій відіграють важливу роль при реалізації євроінтеграційного процесу, побудови інституцій $Є С$, у внутрішньому та міжнародному житті суспільства. Платформа публічних комунікацій використовується для реалізації успішного діалогу, отримання інформації про особливості діяльності країн-членів Європейського Союзу. Вона виконує вирішальну функцію при сприянні й зміцненні відносин як між країнами-членами, так і між громадянами Європейського Союзу. Тому дослідження в сфері публічних комунікацій $\epsilon$ пріоритетними для Європейського Союзу. Їх метою $є$ розвиток нових форм взаємодії та інструментів у сфері публічного управління.

Аналіз останніх досліджень і публікацій. Проблематику становлення та розвитку комунікацій у сфері публічного управління досліджували відомі світові й вітчизняні науковці: Бакулєв Г., Дзялошинський І., Кулі Ч., Лазарсфельд П., Мак-Люен М., Ноель-Нойман Є., Науменко Т., Черних А., Шарков Ф. - досліджували теоретичні аспекти використання системи комунікацій; Антонова О., Бебик В., Бутирська Т., Валевський В., Вировий С., Голубь В., Гонюкова Л., Гурковський В., Карлова В., Климанська Л., Козаков В., Королько В., Куйбіда В., Неліпа Д., Пухкал О., Рашковська О., Ребкало В., Рейтерович І., Серьогін С., Телешун С., Титаренко О. присвятили свої дослідження розгляду концептуальних засад теорій комунікацій у публічному управлінні. Розвиток публічних комунікацій, питання формування та реалізації комунікаційної політики країн ЄС досліджували Ламперт Ц., Макаренко Є., Мікоел П, Парфенюк Є., Фарізеллі П., Петруччо П. При цьому не зважаючи на представлені дослідження, питання розвитку публічних комунікацій, його впливу на взаємодію органів публічної влади поки ще не знайшли свого комплексного вирішення та залишаються малодослідженими. Таким чином, актуальність, недостатня розробленість та теоретичне й практичне значення означеної вище тематики визначило науковий інтерес автора до вивчення особливостей розвитку публічних комунікацій в країнах Європейського Союзу.

Мета статті - дослідження особливостей розвитку публічних комунікацій в країнах Європейського Союзу 3 метою імплементації успішних практик в теперішню українську дійсність.

Виклад основного матеріалу. Процес розвитку публічних комунікацій в країнах Європейського Союзу побудований на чітко визначених принципах та напрямах взаємодії між інститутами влади $€ C$, громадянським суспільством, бізнесом, їх активним залученням до процесів прийняття рішень. 
Суб’єктами процесу розвитку публічних комунікацій в країнах Європейського Союзу виступають інститути державної влади та управління, інститути місцевого самоврядування, політичні партії, політичні лідери, громадські та міжнародні організації, громадяни, комерційні та підприємницькі структури, інші інституції СС.

Процес розвитку публічних комунікацій в країнах Європейського Союзу характеризується наступними інституційними особливостями: 1) надання різним заходам, процесам та явищам певної публічності, гласності, відкритості та прозорості. Для інститутів СС публічний характер є одним із вирішальних чинників їхнього демократичного розвитку; 2) гармонізація та узгодження інтересів всіх учасників. Підтримка стабільності, координація, регулювання відносин, взаємоінтеграція суспільства або його певних груп, оптимізація діяльності й рішень на рівні Союзу; 3) вплив на формування громадської думки та позиції. Роз'яснення розуміння щодо політичних, економічних, соціальних рішень $\mathrm{CC}$; подолання «дефіциту комунікації» між ЄC та громадянами; розвиток комунікації з громадянами держав-членів ЄС про переваги євроінтеграції; посилення демократизації, активне залучення громадян до процесів прийняття важливих рішень.

Основною метою розвитку публічних комунікацій для громадського суспільства в країнах Європейського Союзу $\epsilon$ надання можливості громадянам отримувати зрозумілу й чітку інформацію про свої права, обов'язки та можливості; активно брати участь у формуванні й реалізації політик, мати доступ до інформації про діяльність та політику ЄС.

Процес розвитку публічних комунікацій в країнах Свропейського Союзу побудований на наступних принципах: інклюзивності - який передбачає, що всі громадяни ЄС мають право прозоро отримувати затребувану інформацію; право на свободу висловлювання, яке закріплено ст. 11 Хартії ЄС про основоположні права; усі громадяни мають право на отримання допомоги в розвитку навичок доступу до інформації; різноманітності - яка означає, що ЄC поважати всі точки зору громадян протягом публічних обговорень на різних мовах й каналах; участі - громадяни мають право бути почутими, висловлювати свої точки зору, вступати в діалог із тими, хто приймає важливі рішення. На рівні $€ С$, де існує ризик віддаленості інституцій від громадян, ці принципи мають особливо важливе значення в процесі демократичного розвитку Союзу; принцип єдиного інформаційного поля завдяки прозорому доступу до інформації громадяни ЄС мають можливість висловлювати свої думки, отримувати звітність від інститутів влади ЄС, брати участь у обговоренні важливих питань, реалізовувати свої права.

Яскравим прикладом прогресивного розвитку публічних комунікацій $\epsilon$ успішні практики Німеччини взаємодії інститутів влади із громадськістю 3 метою залучення громадян до процесу прийняття рішень. Так у 2000 р. на основі висновків 70 експертів із різних сегментів громадянського суспільства було оприлюднено Меморандум з е-уряду Німеччини, де е-уряд визначався як здійснення процесу формування громадської думки, вироблення рішень та реалізація функцій у політиці, державі та управлінні 3 широким 
використанням інформаційних технологій [1].

Крім того на федеральному рівні у 2010 р. Парламентом Німеччини була створена Комісія 3 питань Інтернету та цифрового суспільства. III основною функцією стало визначення дій держави в напрямі демократичного розвитку в умовах цифровізації. Основною метою діяльності Комісії з питань Інтернету та цифрового супільства стало зібрання та моніторинг через платформу www.enquetebeteiligung.de ідей та публічних ініціатив громадян за наступними тематиками - економіка й довкілля, захист прав споживачів, культура й медіа, освіта й дослідження, право і внутрішні справи, суспільство й демократія. Громадяни отримали можливість прямого впливу на роботу Парламенту. В подальшому діалог 3 громадським суспільством Німеччини продовжувався й на інших платформах. Наприклад, на платформі http://dialog-ueber-deutschland.de громадяни обговорювали питання майбутнього - «Як німці хочуть жити у майбутньому? Як вони хочуть працювати? Як вони хочуть навчатися?». Результати діалогу 3 експертами було опубліковано; з ініціатив та ідей громадян було обрано 20 пропозицій, автори 10-ти найтоповіших пропозицій отримали запрошення персонально обговорити ідеї з Канцлером. Така взаємодія з громадськістю суттєво підвищила популярність інститутів влади Німеччини [2].

На каналі YouTube федерального уряду транслюються відео 3 актуальних політичних питань. До регулярних відео належать: «Podcast» програма, у якій канцлер розповідає про своє ставлення та очікування від найближчих подій; «3 питання, 3 відповіді», у якій міністри відповідають на поставлені запитання[ 3]. За допомогою Twitter громадяни Німеччини мають можливість спілкуватися безпосередньо з прес-секретарем уряду [4].

Німецька федеральна агенція інформаційних технологій, телекомунікацій та нових медіа у результатах своїх досліджень оприлюднила інформацію, більшість користувачів розглядають Інтернет як засіб просування демократії. Кожен третій громадянин бере участь у виборах через Інтернет, 64 \% молоді віком 18 - 29 років обирає саме цей засіб комунікації, 44 \% німців виявляють інтерес до політичної участі через Інтернет [5].

Нідерланди -країна 3 високим рівнем політичної участі, участі в тренінгах та освіті, інтернет зв'язку та он-лайн комунікації. У 2012 - 2013 рр. країна посіла друге місце з 97 країн за індексом відкритого урядування рейтингом, що складається неурядовою організацією World Justice Project [6]. Індекс включає такі показники, як публічність та доступність законів, стабільність законів, право на звернення до уряду та участь громадськості, доступність офіційної інформації за запитом.

Не менш цікавим й ефективним є досвід залучення громадян у процеси прийняття рішень уряду Франції, який у 2013 р. представив Дорожню карту для цифрової економіки, де одним із наріжних каменів $є$ просування французьких цінностей у суспільстві. Зокрема, наголошено на заохоченні використовувати цифрові засоби, щоб уникнути виключення; формувати довіру громадян до дій уряду; модернізувати публічну політику через 
застосування нових технологій [7]. Ініціативи громадян реалізовувалися й на місцевому рівні (портали - м. Парижі та Ля-Рошелі).

Стратегія електронного врядування Данії визначає такі ініціативи уряду: ефективна цифрова комунікація 3 громадянами, цифрові технології для бізнесу (цифрова пошта для всіх компаній, доступ до даних компаній через бізнес портал, доступні дані для громадськості тощо), IT у школах, цифрова комунікація 3 пацієнтами, IT для реалізації соціальних ініціатив, IT підтримка пошуку роботи, цифрові університети, спільна платформа для ефективного управління довкіллям тощо [8]. Через невеликий розмір країни, де «всі знають усіх», інституційною характерною особливістю Данії вважають консультаційний процес (офіційний та неофіційний) 3 ключовими стейкхолдерами й урядом. Данські міністерства активно проводять процес консультацій через публічні слухання та тематичні веб-сайти щодо стимулювання публічних обговорень та залучення громадян. Уряд Данії займає проактивну позицію щодо доступності урядових положень через Інтернет для широкої громадськості. Так, законодавство друкується в офіційній газеті Lovtidende.dk, яка має електронний формат. Веб-сайт Retsinformation.dk надає доступ до державної правової системи та забезпечує пошук законів, положень, які видають міністерства, урядові органи, за винятком документів, які стосуються поточних парламентських обговорень. Сайт зв’язує з базою парламентського веб-сайту, а також надає доступ до Lovtidende.dk та міністерської газети Ministerialtidende.dk [9]. Як частина урядової програми е-уряду було створено веб-сайт Virk.dk, зорієнтований на бізнес; тут підприємці можуть отримати інформацію 3 питань правил та реєстрації в Данії, отримати зразки документів [10]. Громадський портал Borger.dk забезпечує легкий доступ до сектору публічної інформації, допомагає розв'язати питання, пов'язані з наданням послуг[11].

Сайт Швеції - Sweden.se є офіційним джерелом інформації про державу. Він надає можливість спілкування з упорядниками для отримання відповідей на важливі питання, що стосуються проживання, працевлаштування, туристичних атракцій, статистичної інформації, культури, бізнесового оточення, природи тощо. Окрім шведської публікації сайту доступні такими мовами, як: англійська, арабська, китайська, французька, німецька, російська, іспанська [12]. Швеція також представлена в Facebook та Twitter. Урядовий спеціальний портал eRepublic.org підтримує та сприяє послугам е-уряду в усьому світі й зорієнтований на залучення громадян та розвиток публічних комунікацій[13].

Протягом останніх років у Фінляндії активно обговорюються питання участі громадян у процесах прийняття рішень щодо таких питань як добробут держави, відчуження громадян від політичного процесу та якість публічних послуг. Усі дискусії призвели до розуміння необхідності посилити роль громадянського суспільства та започатковують різноманітні проекти та ініціативи. Доступ до всіх публічних послуг надається через сайт Suomi.fi, де особливу увагу зосереджено на наданні е-послуг. Уся важлива для громадян інформація згрупована за 14 темами, найбільш затребуваними є житло та 
будівництво, соціальні послуги сім'ям, закон і правовий захист, робота та пенсія, оподаткування та фінансування, транспорт і подорожі тощо. Увівши назву муніципалітету, можна отримати інформацію про всі наявні послуги[14]. Забезпечено також зворотній зв'язок; усі запити громадян переадресовуються на сайт Public Service Info, основне завдання якого надавати поради громадянам і скеровувати їх до потрібних служб [15]. Створено веб-сайт www.2030.fi, який надає форум блогерам висловити свою думку щодо майбутнього Фінляндії до 2030 р. [16].

Висновки. Таким чином, всі програми й ініціативи щодо розвитку публічних комунікацій в країнах Європейського Союзу та активізації участі громадян в прийнятті рішень зорієнтовані на забезпечення взаємодії між інститутами влади й громадянським суспільством, консолідацію спільних зусиль задля досягнення спільних цілей.

\section{Jimepamypa:}

1. Gesellschaft für Informatik GI and Verband Deutscher Elektrotechniker VDE (2000): Electronic Government als Schlüssel zur Modernisierung von Staat und Verwaltung. Ein Memorandum des Fachausschusses Verwaltungsinformatik der Gesellschaft für Informatik und des Fachbereichs 1 der Informationstechnischen Gesellschaft im Verband Deutscher Elektrotechniker. [Electronic resource]. - Available at : www.unioldenburg.de/fb3/ lehre/lenk/MEMORA

2. Große K. Discussing Germany's Future: The Evaluation of Federal Online Citizen Participation [Electronic resource] / K. Große. - Available at : http://ipp.oii.ox.ac.uk/sites/ ipp/files/documents/IPP2014_Grosse.pdf

3. Інституційне забезпечення державної комунікативної політики: досвід країн Європи : [аналіт. доп.]. - К. : НІСД, 2014. - 40 с. [Електронний ресурс]. - Режим доступу : http://www.niss.gov.ua/public/File/2014_nauk_an_rozrobku/comunicat_depart.pdf

4. Bundespresseamt [Electronic resource]. - Available at : http://www.bundesregierung.de/ Content/DE/StatischeSeiten/Breg/bundespresseamt-das-amt-imueberblick.html?nn=391634

5. Born S. E-participation enables political participation by electronic means [Electronic resource] / S. Born. - Available at : https://www.alumniportal-deutschland.org/en/ sustainability/politics/article/e-participation-political-participation.html

6. The Rule of Law Index [Electronic resource]. - Available at : http://worldjusticeproject. org/rule-of-law-index

7. eGovernment Factsheets - France [Electronic resource]. - Available at : https://joinup.ec.europa.eu/sites/default/files/09/50/4c/eGov\%20in\%20FR\%20May\%202014\%20 v.\%2016.0.pdf

8. eGovernment Strategy 2011 - 2015. The Danish Government / Danish Regions / Local Government [Electronic resource]. - Available at : http://www.digst.dk/ /media/Files/ Digitaliseringsstrategi/Engelsk_strategi_tilgaengelig.pdf

9. Transparency through consultation and communication [Electronic resource]. Available at : http://www.oecd.org/gov/regulatory-policy/44912510.pdf

10. Virk.dk http://english.virk.dk/home.html

11. Borger.dk https://www.borger.dk/Sider/default.aspx

12. Sweden. Official web-site [Electronic resource]. - Available at : http://sweden.se/

13. eRepublic.org [Electronic resource]. - Available at : http://www.erepublic.org/ egovincountriessesz/sweden.html

14. Suomi.fi [Electronic resource]. - Available at : http://www.suomi.fi/suomifi/ english/index.html 
15. Public Service Info [Electronic resource]. - Available at : http://www.publicserviceinfo.fi/kansalaisneuvonta/en/index.html

16. Citizens involved in shaping the future of Finland [Electronic resource]. - Available at: http://vnk.fi/ajankohtaista/tiedotteet/tiedote/fi.jsp?oid=366665

\section{References:}

1. Gesellschaft für Informatik GI and Verband Deutscher Elektrotechniker VDE: Electronic Government als Schlüssel zur Modernisierung von Staat und Verwaltung. Ein Memorandum des Fachausschusses Verwaltungsinformatik der Gesellschaft für Informatik und des Fachbereichs 1 der Informationstechnischen Gesellschaft im Verband Deutscher Elektrotechniker. (2000). www.unioldenburg.de. Retrieved from www.unioldenburg.de/fb3/ lehre/lenk/MEMORA [in German].

2. Große K. Discussing Germany's Future: The Evaluation of Federal Online Citizen Participation. blogs.oii.ox.ac.uk. Retrieved from http://blogs.oii.ox.ac.uk/ippconference/sites/ipp/files/documents/IPP2014_Grosse.pdf [in German].

3. Instytutsiine zabezpechennia derzhavnoi komunikatyvnoi polityky: dosvid krain Yevropy [Institutional support of state communication policy: the experience of European countries]. (2014). Kyiv: NISD. Retrieved from http://www.niss.gov.ua/public/File/2014_nauk_ an_rozrobku/comunicat_depart.pdf [in Ukrainian].

4. Bundespresseamt. www.bundesregierung.de. Retrieved from https://www.bundesregierung.de/breg-de/bundesregierung/bundespresseamt [in German].

5. Born, S. (2016). E-participation enables political participation by electronic means. www.researchgate.net. Retrieved from https://www.researchgate.net/publication/303912369_Eparticipation_-_a_Key_Factor_in_Developing_Smart_Cities [in German].

6. The Rule of Law Index. worldjusticeproject.org. Retrieved from http://worldjusticeproject.org/rule-of-law-index [in English].

7. eGovernment in France. (2014). European Dynamics SA. Retrieved from https://joinup.ec.europa.eu/sites/default/files/09/50/4c/eGov\%20in\%20FR\%20May\%202014\%20 v.\%2016.0.pdf [in English].

8. eGovernment Strategy 2011-2015. The Danish Government. Danish Regions. Local Government. www.digst.dk. Retrieved from http://www.digst.dk/ /media/Files/ Digitaliseringsstrategi/Engelsk_strategi_tilgaengelig.pdf [in English].

9. Transparency through consultation and communication. (2010). Better Regulation in Europe: Denmark. (pp. 61-67). OECD. Retrieved from http://www.oecd.org/gov/regulatorypolicy/44912510.pdf [in English].

10. Site of Søg på Virk. Virk.dk. Retrieved from http://english.virk.dk/home.html [in Danish].

11. Site of Borger.dk. Retrieved from https://www.borger.dk/Sider/default.aspx [in Danish].

12. Official web-site of Sweden. sweden.se. Retrieved from http://sweden.se/ [in English].

13. Site of eRepublic.org. www.erepublic.org. Retrieved from http://www.erepublic.org/ egovincountriessesz/sweden.html [in English].

14. Site of Suomi.fi. www.suomi.fi. Retrieved from http://www.suomi.fi/suomifi/english/ index.html [in English].

15. Site of Kansalaisneuvonta. www.publicserviceinfo.fi. Retrieved from http://www.publicserviceinfo.fi/kansalaisneuvonta/en/index.html [in Finnish].

16. Citizens involved in shaping the future of Finland. (n.d.). vnk.fi. Retrieved from http://vnk.fi/ajankohtaista/tiedotteet/tiedote/fi.jsp?oid=366665 [in English]. 